\title{
Simulasi Rekonstruksi Citra pada Sensor Brain ECVT (Electrical Capacitance Volume Tomography) dengan Metode ILBP (Iterative Linear Back Projection)
}

\author{
Nita Handayani ${ }^{1^{\star}}$, Kharisma Fajar H. ${ }^{2}$, Freddy Haryanto ${ }^{1}$, Siti Nurul \\ K. ${ }^{1}$,Marlin R. Baidillah ${ }^{3}$, Warsito P. Taruno ${ }^{3}$ \\ ${ }^{1}$ Lab. Biofisika Program Studi Fisika, Fakultas MIPA, Institut Teknologi Bandung, Indonesia \\ ${ }^{2}$ Prodi Fisika, Fakultas Sains dan Teknologi, UIN Sunan Kalijaga Yogyakarta, Indonesia \\ ${ }^{3)}$ Neuroscience Divison, CTech Labs PT Edwar Technology, Tangerang, Indonesia \\ 1*Email: nitahandayani@yahoo.com
}

DOI: http://dx.doi.org/10.13057/ijap.v6i02.1480

\begin{abstract}
The purpose of this study is to simulate the sensor 32-channel Brain ECVT image reconstruction using ILBP (Iterative Linear Back Projection) methods. ECVT is a dynamic volume imaging technique that utilizes non-linear difference of electric field distribution to determine the distribution of permittivity in the sensing area. ECVT has measured the capacitance of data as a result of changes in the permittivity distribution between the electrode pairs. ECVT device consists of three main parts: helmet-shaped sensors, DAS (Data Acquisition System), PC for display and image reconstruction process. Simulation of sensor design using COMSOL Multiphysics 3.5 software, while the process of image reconstruction and analysis of the results using Matlab software 2009a. The principle of ECVT includes two stages of data collection capacitance of electrodes (forward problem) and image reconstruction from the measured capacitance (inverse problem). In the study, the simulation of image reconstruction was done by varying the object position, the number of objects and charge density of the object. From the simulation results showed that the reconstructed image with ILBP method is influenced by several parameters: the object's position in the sensor,charge density value of the object, an alpha value and the number of iterations was selected.
\end{abstract}

Keywords: Brain ECVT, image reconstruction, ILBP method, sensor, simulation

\section{ABSTRAK}

Tujuan penelitian ini adalah melakukan simulasi rekonstruksi citra pada sensor Brain ECVT 32-channel dengan menggunakan metode ILBP (Iterative Linear Back Projection). ECVT merupakan teknik pencitraan volume dinamik yang memanfaatkan perbedaan non linear dari perbedaan distribusi medan listrik untuk menentukan distribusi permitivitas dalam area yang disensing. ECVT mengukur data kapasitansi sebagai hasil perubahan distribusi permitivitas antara pasangan elektroda kapasitansi. Perangkat ECVT terdiri dari tiga bagian utama yaitu sensor berbentuk helm, DAS (Data Acquisition System) dan PC untuk display dan proses rekonstruksi citra. Simulasi desain sensor dengan menggunakan software COMSOL Multiphysics 3.5 sedangkan proses rekonstruksi citra dan analisis hasil menggunakan software Matlab 2009a. Prinsip kerja ECVT meliputi 2 tahapan yaitu pengumpulan data kapasitansi dari elektroda (forward problem) dan rekonstruksi citra dari data kapasitansi terukur (invers problem). Pada penelitian, simulasi rekonstruksi citra dilakukan dengan memvariasikan posisi objek dalam sensor, jumlah objek dan rapat muatan objek. Dari hasil simulasi diperoleh hasil bahwa citra rekonstruksi dengan metode ILBP dipengaruhi oleh beberapa parameter yaitu posisi objek dalam sensor, rapat muatan objek, nilai alfa dan jumlah iterasi yang dipilih. 


\section{PENDAHULUAN}

Brain ECVT (Electrical Capacitance Volume Tomography) merupakan sistem ECVT yang digunakan untuk studi aktivitas kelistrikan otak manusia. ECVT merupakan suatu teknik pencitraan volume dinamis yang dikembangkan berdasarkan sistem ECT (Electrical Capacitance Tomography). Pada awal pengembangannya, ECVT digunakan untuk pencitraan distribusi dielektrik dari material dielektrik dengan kontras tinggi ${ }^{[1]}$. Dalam dunia industri ECVT telah digunakan untuk studi gas-solid fluidized bed system ${ }^{[2]}$ dan gas-solid Circulating Fludized Bed (CFB) sehingga diperoleh citra aliran multiphase 3 dimensi $^{[3]}$.

Selanjutnya, ECVT dikembangkan untuk aplikasi dalam bidang medis salah satunya yaitu Brain ECVT. Telah dilakukan beberapa studi untuk pengembangan sistem ECVT mencakup desain sensor dan teknik rekonstruksi citra. Hasil studi tentang desain sensor menyatakan bahwa geometri hexagonal merupakan desain paling optimum dari sensor ECVTdari keempat geometri sensor yang diuji (hexagonal, rectangular, trapezoid dan triangular). Geometri ini memiliki variasi distribusi medan listrik dalam arah aksial dan intensitas yang uniform serta hasil pencitraan yang lebih bagus dibandingkan geometri yang lain. Elektroda hexagonal yang disusun secara horisontal menunjukkan konsistensi yang paling baik dalam menghasilkan citra rekonstruksi ${ }^{[4]}$. Kombinasi elektroda hexagonal dan pentagonal ini digunakan sebagai dasar pembuatan sensor Brain ECVT yang berbentuk helm.

Brain ECVT dikenal sebagai multimodal imaging dengan kelebihan berupa teknologi nonradiatif, non-invasif, metode rekonstruksi citra cepat, dan murah (low cost). Sensor tomografi kapasitansi Brain ECVT terdiri dari 32 elektroda yang dibuat berbentuk helm. Elektroda-elektroda ini berfungsi sebagai plat seperti halnya pada kapasitor sedangkan ruang didalamnya adalah dielektrik. Salah satu plat elektroda sebagai sumber muatan sedangkan plat yang lainnya diaktifkan bergantian sebagai detektor untuk mengukur kapasitansi, sehingga diperoleh distribusipermitivitasuntuk direkonstruksi menjadi citra 3D.

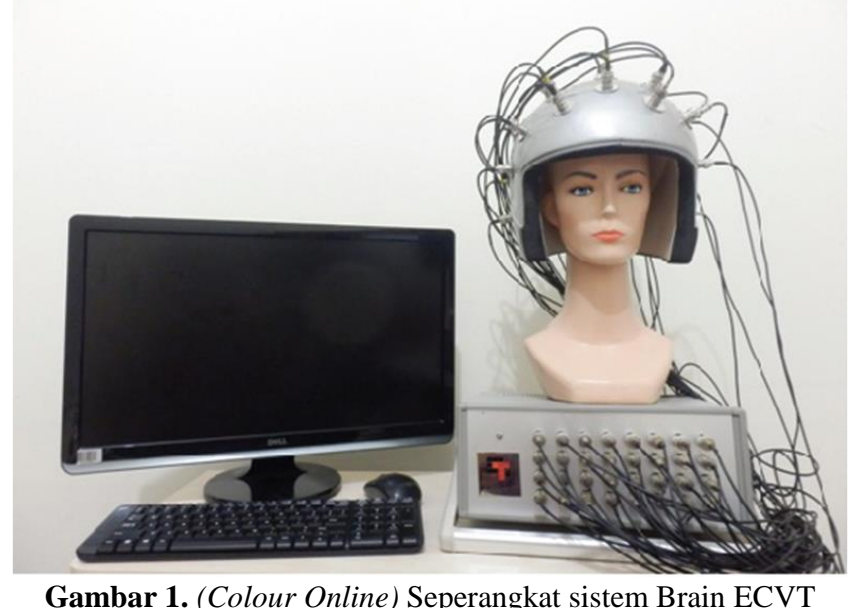

Sistem ECVT terdiri dari tiga bagian utama yaitu elektroda sensor, seperangkat sistem akuisisi data (DAS, Data Acquisition System), PC untuk display dan proses rekonstruksi citra (gambar 1). Perangkat akuisisi data berguna sebagai pengontrol sekaligus pembaca data. Instrumen ini akan mengukur nilai kapasitansi antara plat sumber dengan plat detektor, memindahkan pembacaan dari satu detektor ke detektor lainnya dengan menggunakan Multiplexer, dan data yang telah diukur akan secara langsung dikirimkan ke database 
komputer ${ }^{[5]}$. Nilai kapasitansi $C_{i}$ dari pasangan ke- $i$ antara elektroda sumber dan elektroda detektor dengan luas area detektor $A_{i}$ dapat dituliskan sebagai berikut:

$$
C_{i}=-\frac{1}{\Delta V_{i}} \oiint_{A_{i}} \varepsilon(x, y, z) \nabla \phi(x, y, z) d A
$$

Persamaan (1) menunjukkan adanya hubungan antara kapasitansi dengan sebaran permitivitas pada suatu volume. Pada persamaan tersebut terdapat dua variabel yang saling dependen yaitu distribusi potensial dan distribusi permitivitas.

ECVT masih tergolong modalitas yang cukup baru khususnya untuk studi kelistrikan otak manusia. Oleh karena itu perlu banyak pengembangan dan perbaikan agar diperoleh citra objek yang lebih akurat. Salah satu parameter yang mempengaruhi kualitas citra ECVT adalah metode rekonstruksi citra yang dipilih. Ada beberapa algoritma rekonstruksi citra untuk tomografi kapasitansi seperti yang direview oleh Isaken (1996). Secara umum, algoritma rekonstruksi citra dapat dikategorikan dalam 2 kelompok, yaitu algoritma noniteratif (single step) dan algoritma iteratif. Algoritma non iterative mencakup Linear Back Projection (LBP), direct method based on singular value decomposition, Tikhonov regularization, multiple linear regression and regularization. Sedangkan algoritma iterative mencakup metode Newton-Raphson dan iterative Tikhonov, iterasi Landweber dan steepest descent method, model based iteration, teknik rekonstruksi algebraic dan teknik rekonstruksi iterative simultan ${ }^{[6]}$. Pada penelitian ini akan dikaji tentang teknik rekonstruksi citra ECVT dengan algoritma Iterative Linear Back Projection (ILBP). Simulasi rekonstruksi citra dilakukan dengan memvariasikan posisi objek, jumlah objek dan rapat muatan objek yang diletakkan dalam sensor Brain ECVT.

\section{METODE}

\section{Metode Rekonstruksi Citra}

Prinsip kerja ECVT mencakup pengumpulan data kapasitansi dari elektroda-elektroda yang ditempatkan di sekeliling objek (forward problem) dan rekonstruksi citra dari data kapasitansi terukur (inverse problem). Forward problem dibahas secara umum dalam tiga pendekatan yaitu teknik linierisasi ${ }^{[7,8,9]}$, metode numerik brute-force seperti metode elemen hingga, dan metode analitik. Metode analitik dapat memberikan solusi yang akurat dan relatif cepat, tetapi terbatas untuk geometri yang sangat sederhana dengan distribusi permitivitas simetris, dan tidak berlaku untuk sistem tomografi industri dengan struktur dinamis yang kompleks. Sedangkan metode numerik dapat memberikan solusi cukup akurat untuk distribusi yang berubah-ubah, tetapi memerlukan waktu komputasi yang lama sehingga tidak praktis untuk aplikasi tomografi dengan rekonstruksi citra iteratif. Dalam hal ini, metode linierisasi memberikan solusi sederhana dan relatif cepat, meskipun menunjukkan efek smoothing pada batas tajam citra yang direkonstruksi. Efek smoothing ini meningkat dengan iterasi dalam proses rekonstruksi citra ${ }^{[10]}$.

Teknik linierisasi dengan menggunakan model sensitivitas ${ }^{[7,8]}$ didasarkan pada teorema superposisi jaringan listrik dimana domain(volume yang dilingkupi oleh sensor) dibagi menjadi beberapa voxel (volume elemen). Respon dari sensor merupakan penjumlahan linier dari respon voxel-voxel individual ketika terjadi perubahan permitivitas. Besarnya sensitivitas dapat ditentukan dengan persamaan berikut ${ }^{[11]}$ :

$$
S_{i j} \cong V_{0 j} \frac{\vec{E}_{s i}(x, y, z) \cdot \vec{E}_{d i}(x, y, z)}{V_{s i} V_{d i}}
$$


Dimana $\vec{E}_{s i}(=-\nabla \phi)$ adalah vektor distribusi medan listrik ketika pasangan elektroda sumber ke- $i$ diaktivasi dengan tegangan $V_{s i}$ sedangkan elektroda lainnya digroundkan. $\vec{E}_{d i}$ adalah vektor distribusi medan listrik ketika pasangan elektroda detektor diaktivasi dengan tegangan $V_{d i}$ dan elektroda lainnya digroundkan. $V_{0 j}$ adalah volume voxel ke-j. Bentuk persamaan yang sudah dilinierkan dari persamaan (1) dapat dituliskan dalam bentuk matriks sebagai berikut:

$$
C=S G
$$

Dimana $\boldsymbol{C}$ adalah vektor data kapasitansi $M$-dimensi, $\boldsymbol{G}$ adalah vector citra $N$-dimensi, $N$ adalah jumlah voxel dalam domain (bernilai 32768) dan $M$ adalah jumlah kombinasi pasangan elektroda (bernilai 496 untuk sensor 32-elektroda). Matriks sensitivitas $S$ mempunyai dimensi $M \times N$. Cara yang paling sederhana untuk memperkirakan vektor citra $\boldsymbol{G}$ adalah menggunakan teknik proyeksi balik ${ }^{[12]}$ yaitu:

$$
G=S^{T} C
$$

Semua data pengukuran adalah proyeksi balik sederhana untuk memperkirakan citra. Teknik ini disebut sebagai proyeksi balik linier (LinearBackProjection, LBP). Rekonstruksi citra dilakukan dengan menggunakan software Matlab 2009a. Data yang digunakan untuk proses rekonstruksi adalah data sensitivitas matriks dan data pengukuran kapasitansi ternormalisasi. Diagram alir proses rekonstruksi citra ILBP ditunjukkan pada gambar $2^{[13]}$.

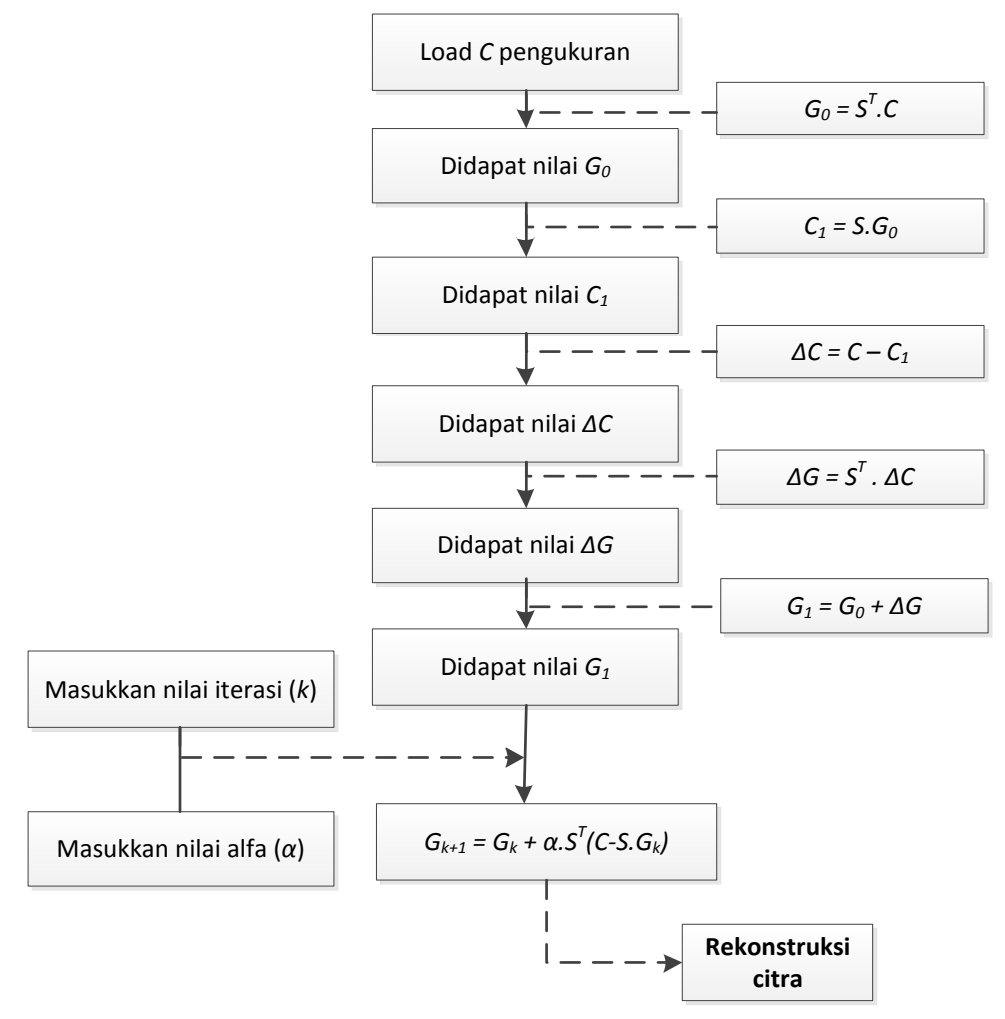

Gambar 2. Diagram alir proses rekonstruksi citra metode ILBP

Nilai alfa $(\alpha)$ merupakan konstanta untuk mengontrol laju konvergensi dan $k$ menunjukkan jumlah iterasi. Pada penelitian ini, jumlah iterasi divariasikan dari $1 \mathrm{~s} / \mathrm{d} 200$ dan nilai alfa dipilih dari 0,1 s/d 1,5 dengan interval kenaikan sebesar 0,1. 
Simulasi desain sensor sistem ECVT menggunakan software COMSOL Multiphysics 3.5 dengan memanfaatkan prinsip metode elemen hingga (Finite Element Method). Sensor Brain ECVT yang digunakan dalam penelitian berbentuk helm, yang tersusun atas 32 elektroda. Elektroda sensor merupakan kombinasi 6 elektroda segilima dan 26 elektroda segienam. Geometri sensor dibuat menyesuaikan dengan geometri kepala manusia seperti yang ditunjukkan pada gambar 3 .
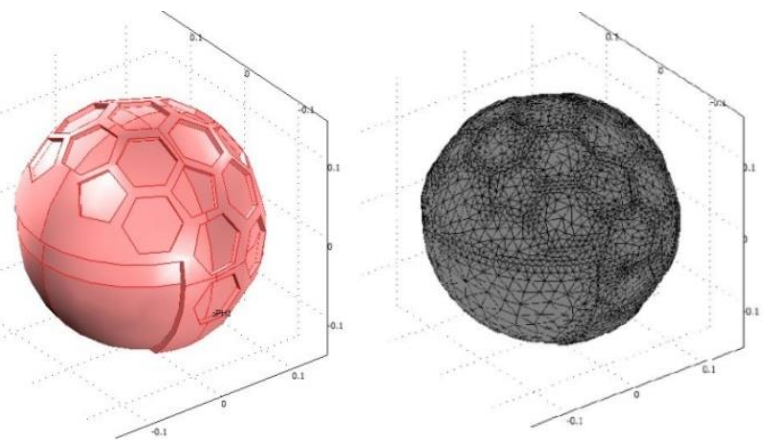

Gambar 3. (Colour Online) Desain sensor dan hasil meshing sensor BrainECVT

Parameter fisika yang digunakan dalam desain sensor adalah parameter subdomain, parameter boundary, parameter meshing, parameter solve problem dan post-processing yang terdapat dalam software COMSOL Multiphysics 3.5.

\section{Simulasi Sensor ECVT}

Simulasi rekonstruksi citra pada sensor Brain ECVT dilakukan dengan memvariasikan:

a. Posisi objek di dalam sensor

Pada simulasi variasi posisi objek di dalam sensor, nilai permitivitas relatif $\left(\varepsilon_{r}\right)$ objek diberikan sebesar 604,55 yang merupakan nilai $\varepsilon_{r}$ dari grey matter (lapisan otak). Frekuensi pada DAS diset sebesar 2,5 MHz. Variasi posisi objek di dalam sensor ECVT seperti terlihat pada gambar 4 .

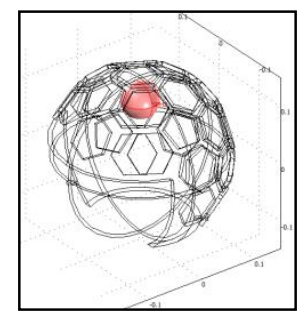

Objek di atas (O1)

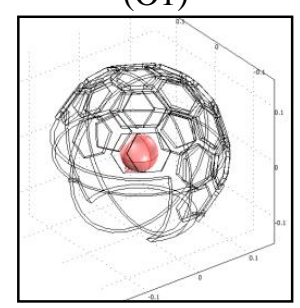

Objek ditengah (O6)

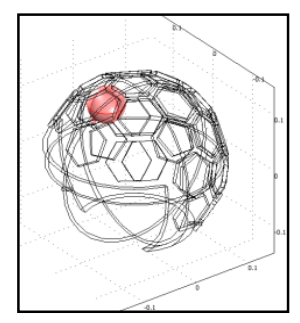

Objek di kanan-atas $(\mathrm{O} 2)$

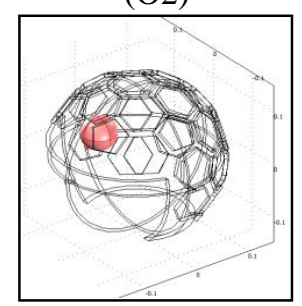

Objek di kanantengah $(\mathrm{O} 7)$

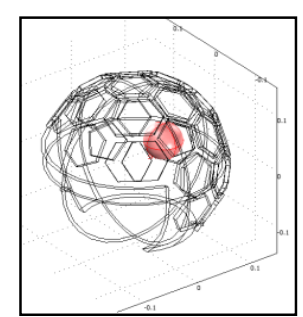

Objek di kiri-atas (O3)

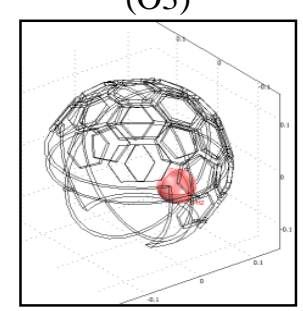

Objek di kiri-tengah (O8)

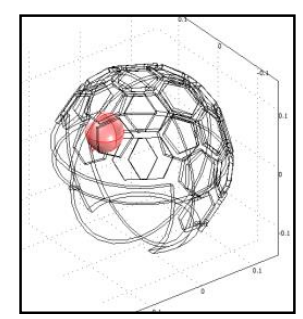

Objek di depan-atas

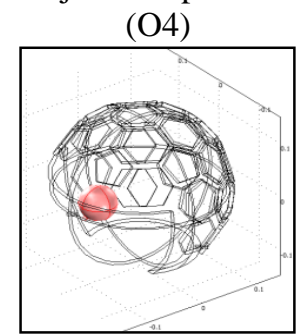

Objek di depantengah (O9)

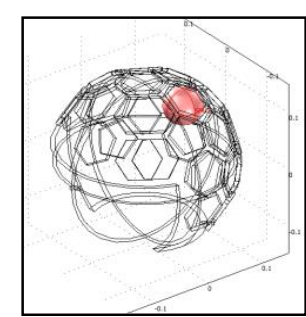

Objek di belakangatas (O5)

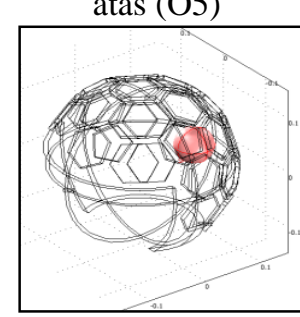

Objek di belakangtengah (O10) 


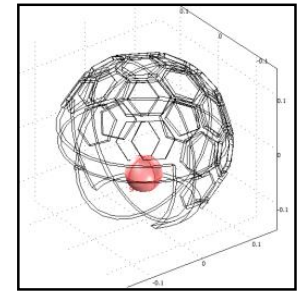

Objek di bawah (O11)

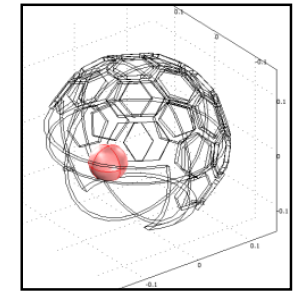

Objek di kananbawah (O12)

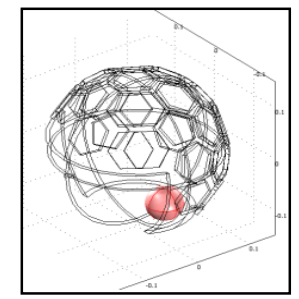

Objek di kiri-bawah (O13)

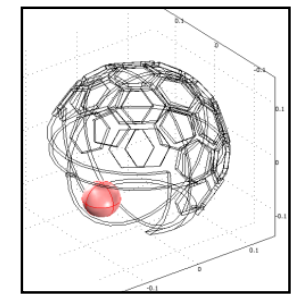

Objek di depanbawah (O14)

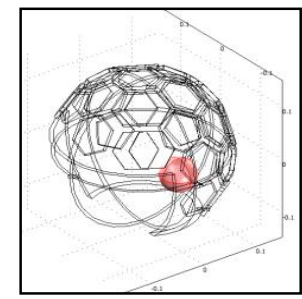

Objek di belakangbawah (O15)

Gambar 4. (Colour Online) Variasi posisi objek dalam sensor ECVT

b. Variasi jumlah objek di dalam sensor

Variasi jumlah objek dalam sensor ECVT berupa 2 objek (kanan-kiri), 2 objek (depanbelakang) dan 4 objek (kanan-kiri-depan-belakang) seperti terlihat pada gambar 5 .
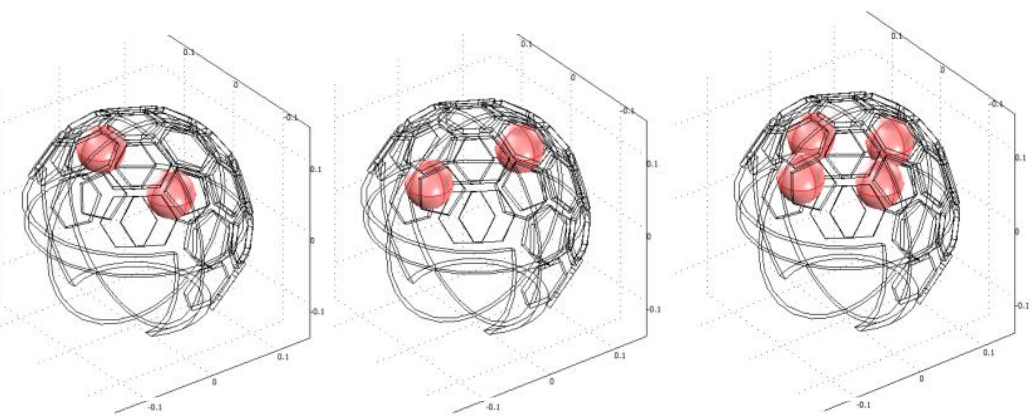

Gambar 5. (Colour Online) Variasi jumlah objek dalam sensor ECVT

c. Simulasi objek yang diberi rapat muatan.

Pada kedua objek diberi nilai permitivitas relatif yang sama yaitu $\varepsilon_{r}=604,55$ dengan salah satu objek diberi rapat muatan sebesar $4.10^{-3} \mathrm{C} / \mathrm{m}^{3}$ (gambar 6).

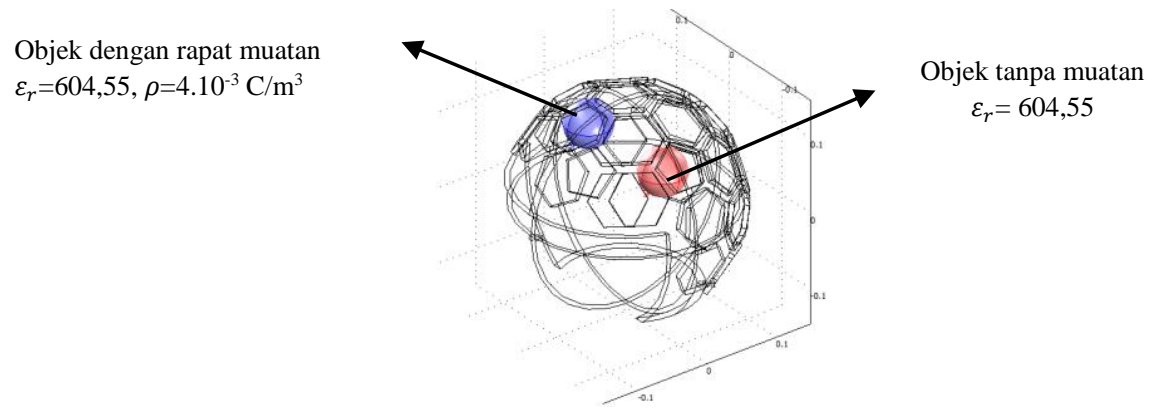

Gambar 6. (Colour Online) Posisi objek bermuatan dalam sensor ECVT

\section{HASIL DAN PEMBAHASAN}

\section{Distribusi Sensitivitas}

Pada pencitraan objek 3 dimensi memerlukan sebuah matriks sensitivitas dengan tambahan variasi dalam arah axial (sumbu-z) yang searah dengan kedalaman sensor. Sensitivitas dipengaruhi oleh intensitas medan listrik yang terdistribusi dalam domain sensor ECVT. Pada proses rekonstruksi iteratif, konvergensi ditentukan oleh variasi (perbedaan nilai maximum dan minimum pada satu level) dan smoothness dari slope kurva distribusi sensitivitas sepanjang arah axial. Jika variasi lebih besar dan slope kurva lebih smooth maka 
proses iterasi lebih mudah mencapai konvergensi ${ }^{[10]}$. Kurva pada gambar 7 menyatakan nilai sensitivitas dari 496 pasang elektroda sensor Brain ECVT untuk 32 level.

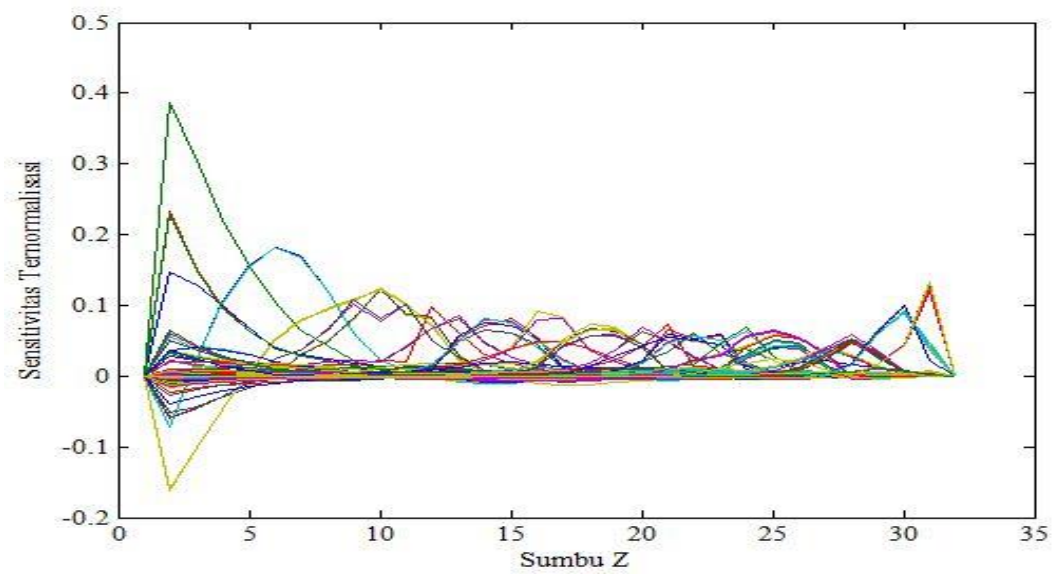

Gambar 7. (Colour Online) Grafik distribusi sensitivitas ternormalisasi pada sumbu-z

\section{Hasil Rekonstruksi Citra Variasi Posisi Objek}

Citra hasil rekonstruksi menggunakan metode ILBP dengan permitivitas relatif $\varepsilon_{r}$ objek 604,55 ditampilkan pada gambar 8. Posisi objek dalam sensor sangat mempengaruhi citra rekonstruksi yang dihasilkan. Saat objek diletakkan di dekat sensor (O1, O2, O3, O5), terlihat citra potongan axial slice ke-26 yang dihasilkan hampir sama dengan objek aslinya. Pada objek yang diletakkan di bagian depan-atas (O4), citra yang diperoleh seperti tertarik memanjang. Distorsi bentuk ini terjadi karena distribusi sensitivitas di daerah tersebut lebih kuat dibandingkan daerah sekitarnya. Sedangkan efek blur yang muncul pada citra hasil rekonstruksi $(\mathrm{O} 9, \mathrm{O} 14, \mathrm{O} 15)$ menjadikan citra terlihat lebih besar ukurannya dari objek aslinya. Hal ini disebabkan objek tersebut kemungkinan berada di daerah dead zone, yaitu suatu daerah yang tidak dilingkupi sensor sepenuhnya akibatnya distribusi sensitivitas lemah sehingga perubahan data kapasitansi tidak terbaca.

Grafik hubungan antara jumlah iterasi dengan nilai eror untuk beberapa variasi nilai alfa ditunjukkan dalam gambar 9. Tiap garis pada grafik mewakili setiap nilai alfa dengan jumlah iterasi sebanyak 200. Berdasarkan hasil analisis grafik, terlihat bahwa nilai eror terkecil yang terukur yaitu 0,5639 pada iterasi ke-16 untuk alfa 1,4. Pada keadaan tersebut, citra rekonstruksi yang dihasilkan merupakan citra yang paling baik diantara citra lainnya. 

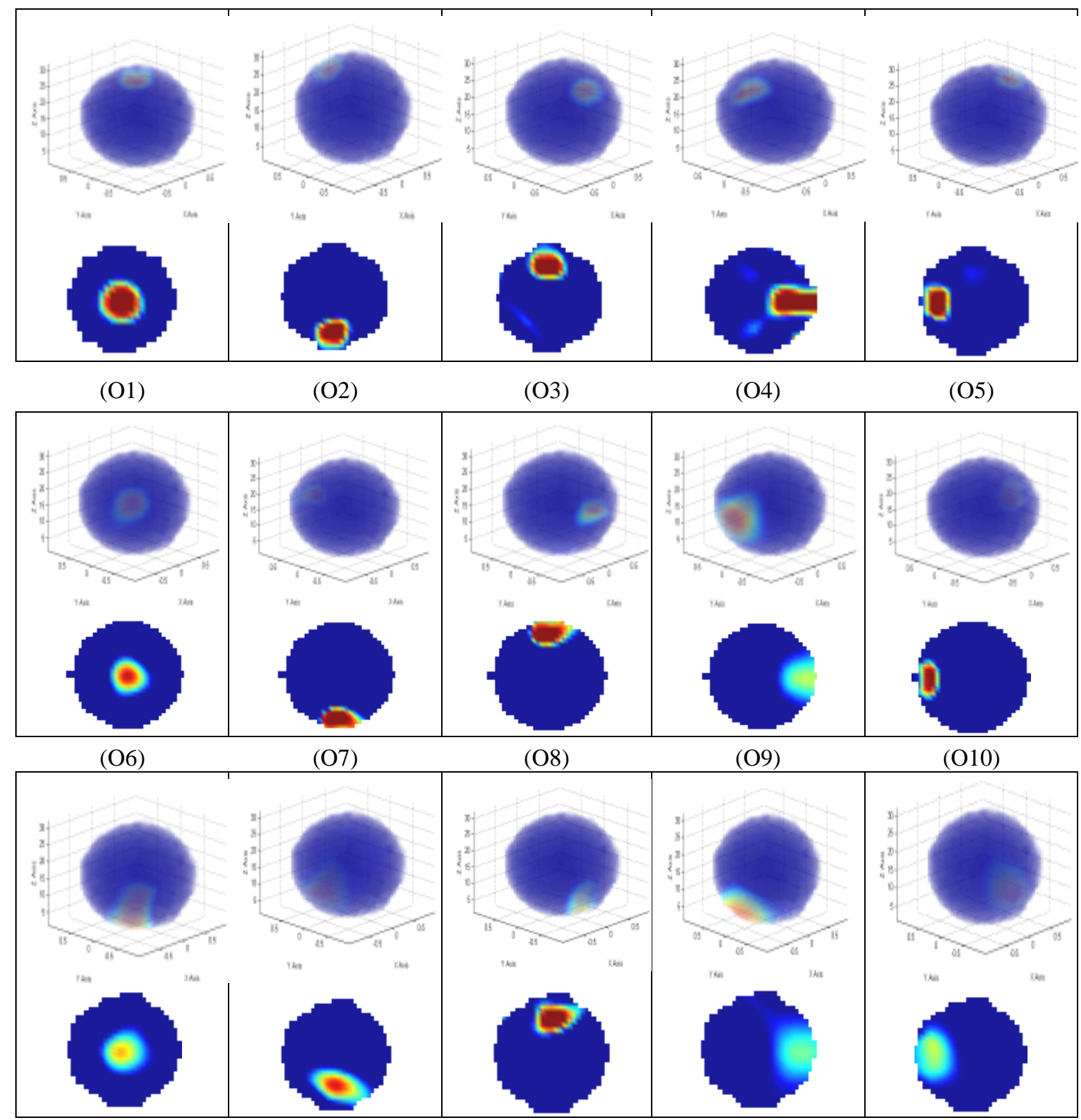

(O11) (O12) (O13)

(O14)

(O15)

Gambar 8. (Colour Online) Citra hasil rekonstruksi ILBP dengan variasi posisi objek

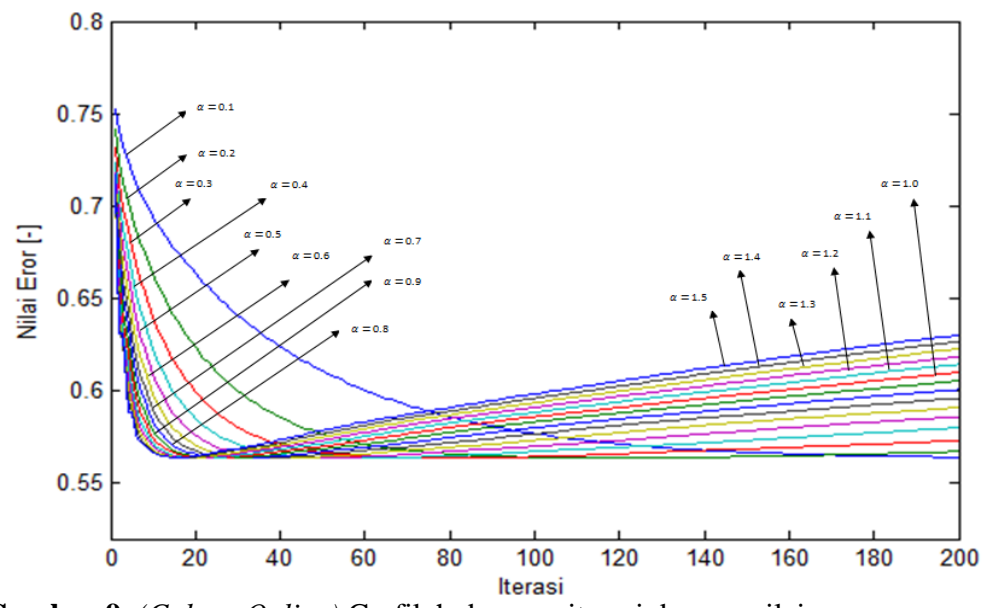

Gambar 9. (Colour Online) Grafik hubungan iterasi dengan nilai eror 


\section{Hasil Rekonstruksi Citra Variasi Jumlah Objek dan Rapat Muatan dalam Sensor}

Citra hasil rekonstruksi dengan variasi jumlah objek dalam sensor ditampilkan dalam gambar 10. Hasil rekonstruksi citra dengan dua objek pada sensor yang diletakkan di posisi kanan-kiri tampak sesuai dengan objek aslinya. Sedangkan untuk posisi depan-belakang, citra rekonstuksi objek di bagian belakang sensor tampak memanjang.

Rapat muatan pada objek diibaratkan seperti aktivitas sinyal listrik dalam otak. Pada simulasi, digunakan prinsip elektrostatik sehingga muatan dianggap statis. Berdasarkan gambar 11, citra yang tampak hanya pada objek yang bermuatan saja sedangkan objek yang tidak bermuatan tidak tampak. Artinya apabila terdapat aktivitas kelistrikan dalam otak akibat adanya stimulus, maka kapasitansi yang terukur menjadi lebih tinggi.

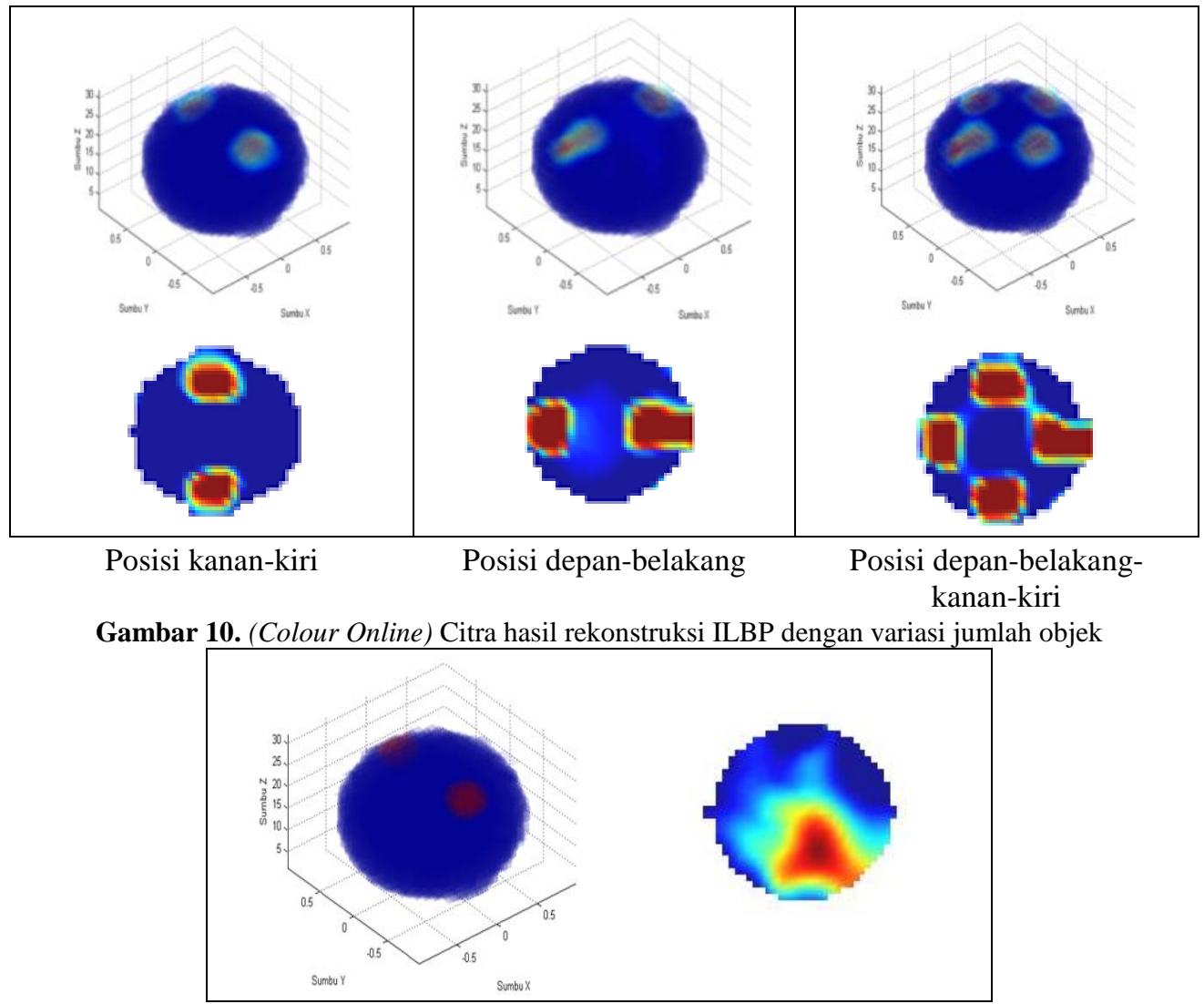

Gambar 11. (Colour Online) Citra hasil rekonstruksi ILBP dengan variasi rapat muatan objek

Berdasarkan analisis data hasil simulasi rekonstruksi citra dengan metode ILBP maka diperoleh beberapa parameter yang berpengaruh pada citra hasil rekonstruksi sensor Brain ECVT. Parameter yang mempengaruhi yaitu posisi objek dalam sensor, nilai alfa dan jumlah iterasi yang dipilih. Pada rekontruksi ILBP, citra yang diperoleh cukup baik pada alfa 1,5 dan iterasi ke-16.

\section{KESIMPULAN}

Teknik rekonstruksi citra dengan metode ILBP telah berhasil diterapkan untuk simulasi citra pada sensor Brain ECVT. Berdasarkan hasil simulasi, diperoleh bahwa posisi objek dalam sensor berpengaruh terhadap kualitas citra yang dihasilkan. Posisi objek terkait dengan tingkat homogenitas distribusi sensitivitas di seluruh area sensor. Distribusi sensitivitas ini sangat berpengaruh untuk mencegah terjadinya distorsi citra atau artefak. Parameter lain 
yang juga berpengaruh yaitu nilai alfa $(\alpha)$ dan jumlah iterasi $(k)$ yang dipilih dalam proses rekonstruksi.

\section{DAFTAR PUSTAKA}

1 Nurge M. A.2007. Electrical Capacitance Volume Tomography of High Contrast Dielectrics using A Cuboid Geometry. Dissertation. University of Central Florida, Orlando, Florida.

2 Du B., Q. Marashdeh, W. Warsito, A. Park, L.S. Fan. 2007. Development of Electrical Capacitance Volume Tomography (ECVT) and Electrostatic Tomography (EST) for 3D Density Imaging of Fluidized Bed System.The $12^{\text {th }}$ International Conference on Fluidization - New Horizons in Fluidization Engineering, pp. 473-480.

3 Wang F., Marashdeh Q., Wang A., and Fan L.S. 2012. Article : Electrical Capacitance Volume Tomography Imaging of Three Dimensional Flow Structures and Solids Concentration Distributions in a Riser and a Bend of a Gas-Solid Circulating Fluidized Bed. Industrial \& Engineering Chemistry Research. ACS Publications, pp.1096810976.

4 Baidillah, M. R., Mukhlisin M., and Taruno, W. P. 2013. Comparison of Sensor Geometries for Electrical Capacitance Volume Tomography. International Journal of Innovative Computing, Information and Control. Vol. 9, No. 11, November, ISSN 1349-4198, pp. 1447-1457.

5 Wang F., Marashdeh Q., L.S. Fan.2010. Electrical Capacitance Volume Tomography: Design and Applications.Sensors, 10, ISSN 1424-8220, pp.1890-1917.

6 Isaken $\phi$. 1996. A Review of Reconstruction Techniques for Capacitance Tomography. Meas. Sci. Technol. 7:325-337, Institute of Physics Publishing.

7 Huang S. M., A. Plaskowski, C. G. Xie, and M. S. Beck. 1989. Tomographic Imaging of Two-Component Flow Using Capacitance Sensors. J. Phys. E: Sci., Vol. 22 (3), pp. 173-177.

8 Xie C. G., S. M. Huang, B. S. Hoyle, R. Thorn, C. Lean, D. Snowden, and M. S. Beck. 1992. Electrical Capacitance Tomography for Flow Imaging System Model for Development of Image Reconstruction Algorithms and Design of Primary Sensor. Proc. Inst. Elect. Eng. G, Vol. 139, No. 1, pp.89-98.

9 Marashdeh Q. and F. L. Teixeira. 2004. Sensitivity Matrix Calculation for Fast3-D Electrical Capacitance Tomography (ECT) of Flow Systems. IEEE Trans. Magn.Vol. 40 (2), pp. 1204-1207.

10 Warsito, W., Marashdeh Q., and Fan L.S. 2007. Electrical Capacitance Volume Tomography. IEEE Sensors Journal. Vol. 7, No. 4, April, pp. 525-535.

11 Lionheart W. R. B. 2001. Reconstruction Algorithms for Permitivity and Conductivity Imaging. Proc. 2nd World Congr. Industrial Process Tomography. Hannover, Germany, pp. 4-11.

12 Yang W. Q., Spink D. M., York T. A., and H McCann. 1999. An Image Algorithm Based on Landweber's Iteration Method for Electrical Capacitance Tomography. IOP Publishing Ltd. Vol. 10, pp. 1065-1069.

13 Nita Handayani, Siti Nurul K., Idam Arif, Freddy H., Warsito P. Taruno. 2015. Investigation of The Music's Effect on Human Brain Activity Using ECVT Brain Scanner and EEG. Advanced Science, Engineering and Medicine (ASEM) Journal. Vol. 7, No. 10, pp. 882-887. 